Красинский Владислав Вячеславович кандидат юридических наук, эксперт Российского общественного института избирательного права (РОИИП)

Источник публикации: Красинский В.B. Правовой режим земель обороны и безопасности // Военно-юридический журнал. 2007. № 7. С. 19-29; www.krasinskiy.ru

\title{
ПРАВОВОЙ РЕЖИМ ЗЕМЕЛЬ ОБОРОНЫ И БЕЗОПАСНОСТИ
}

В последние годы в Российской Федерации в связи с развитием рыночного хозяйствования, ипотечного кредитования и жилищного строительства активизировался оборот земельных участков. Рост числа сделок с недвижимым имуществом, расширение экономической свободы хозяйствующих субъектов далеко не всегда происходили с соблюдением правовых требований. Неурегулированность вопросов разграничения собственности на землю и неправильное толкование отдельных положений Федерального закона от 25.10.2001 г. № 137-Ф3 «О введении в действие Земельного кодекса Российской Федерации» органами местного самоуправления привели к тому, что в сферу гражданского оборота были неправомерно вовлечены земельные участки из состава земель промышленности и иного специального назначения, в том числе земли обороны и безопасности. Нарушения законности при разграничении земельного и имущественного фонда повлекли за собой самовольные захваты земель, ликвидацию многих важнейших объектов военной инфраструктуры, расхищение имущества и нанесли существенный вред обороноспособности и безопасности России.

Необходимо отметить, что несмотря на продолжающееся сокращение Вооруженных Сил и иных воинских формирований Российской Федерации, передачу движимого и недвижимого военного имущества органам местного самоуправления и отдельным хозяйствующим субъектам, демилитаризацию экономики, земли обороны и безопасности продолжают играть важную роль в функционировании оборонно-промышленного комплекса, в системе 
национальной безопасности Российской Федерации, в обеспечении режима защиты государственной тайны.

Регулирование правового режима земель обороны и безопасности является комплексным и включает в себя нормативные предписания целого ряда отраслей законодательства (земельного, градостроительного, лесного, природоохранного, гражданского, административного). $\mathrm{B}$ открытой отечественной юридической литературе правовой режим земель обороны и безопасности глубоко не изучался. Отдельные аспекты правового режима земель данного вида рассматривались в работах С.А. Боголюбова, Б.В. Ерофеева, Ю. Г. Жарикова, Н.И. Калинина, Н.И. Краснова, О.И. Крассова, М.Ю. Тихомирова, В.Х. Улюкаева, Г.В. Чубукова ${ }^{1}$. Однако зарубежный опыт правового регулирования данного вида земель, вопросы предоставления земельных участков обороны и безопасности в аренду или безвозмездное срочное пользование юридическим лицам и гражданам, особенности правового режима земель обороны и безопасности при проведении зонирования территорий, особенности перевода данного вида земель и лесопользования на земельных участках обороны и безопасности остались не освященными.

Отсутствие современных научных исследований, посвященных землям обороны и безопасности, постоянное обновление законодательства о недвижимости, продолжающаяся земельная реформа, потребности практической деятельности Вооруженных Сил Российской Федерации, воинских формирований, организаций и органов, обеспечивающих обороноспособность и безопасность страны, общегосударственная значимость земель обороны и безопасности определяют актуальность представленной работы.

В настоящей статье правовой режим земель обороны и безопасности рассматривается как система правовых норм, определяющих целевое назначение, порядок использования и управления, оборотоспособность, субъективные права, юридические обязанности и ответственность 
участников земельных правоотношений, правовую охрану и мониторинг земель обороны и безопасности. Как представляется, изучение правового режима этих земель позволит выявить пробелы правового регулирования земельных отношений, содержанием которых выступают правомочия по поводу земель обороны и безопасности, а также будет способствовать дальнейшей разработке теоретических и правовых основ земельного права и смежных отраслей, имеющих отношение к рассматриваемой проблематике.

В соответствии со ст. 7, ч. 1 и 5 ст. 87 Земельного кодекса Российской Федерации (далее - ЗК РФ) земли обороны и безопасности рассматриваются в качестве самостоятельного вида земель (субкатегории) из состава категории земель промышленности и иного специального назначения.

Ст. 93 ЗК РФ устанавливает, что землями обороны и безопасности признаются земли, которые используются или предназначены для обеспечения деятельности Вооруженных Сил Российской Федерации, других войск, воинских формирований и органов, организаций, предприятий, учреждений, осуществляющих функции по вооруженной защите целостности и неприкосновенности территории Российской Федерации, защите и охране Государственной границы Российской Федерации, информационной безопасности, другим видам безопасности в закрытых административнотерриториальных образованиях, и права на которые возникли у участников земельных отношений по основаниям, предусмотренным Земельным кодексом и федеральными законами.

Законодателем раскрывается понятие «обеспечение деятельности Вооруженных Сил Российской Федерации, других войск, воинских формирований и органов, организаций, предприятий, учреждений» и тем самым в рамках целевого назначения конкретизируются задачи использования и предоставления земельных участков обороны и безопасности. В качестве основной цели названо «обеспечение обороны», реализуемое посредством: 
1) строительства, подготовки и поддержания в необходимой готовности Вооруженных Сил Российской Федерации, других войск, воинских формирований и органов (размещение военных организаций, учреждений и других объектов, дислокация войск и сил флота, проведение учений и иных мероприятий);

2) разработки, производства и ремонта вооружения, военной, специальной, космической техники и боеприпасов (испытательных полигонов, мест уничтожения оружия и захоронения отходов);

3) создания запасов материальных ценностей в государственном и мобилизационном резервах (хранилища, склады и др.).

Однако данная формулировка целевого назначения земель обороны и безопасности имеет ряд недостатков. Во-первых, обеспечение обороны не может исчерпываться только тремя перечисленными в ЗК РФ составляющими, подтверждением чему служит ст. 2 Федерального закона от 31 мая 1996 г. № 61-Ф3 (в ред. от 04.12.2006 г.) «Об обороне». Во-вторых, в ст. 93 ЗК РФ отсутствует такой элемент целевого назначения земель обороны и безопасности, как обеспечение безопасности. Следуя логике, законодатель должен был дать перечень задач использования и предоставления земельных участков, связанных и с нуждами безопасности.

В связи с этим предлагается ст. 93 ЗК РФ дополнить п. 3 следующего содержания: «В целях обеспечения безопасности могут предоставляться земельные участки для:

1) размещения воинских формирований, органов и учреждений, осуществляющих в пределах своих полномочий решение задач по обеспечению правопорядка, общественной и государственной безопасности;

2) обеспечения защиты сведений, составляющих государственную тайну;

3) осуществления разведывательной, контрразведывательной и оперативно-розыскной деятельности. 
Нумерация существующих пунктов ст. 93 ЗК РФ меняется: п. 3 на п.4, п.4 на п.5, п.5 на п.6, п.6 на п.7, п.7 на п.8.

Более удачным с точки зрения юридической техники является абстрактное и лаконичное определение данного вида земель, содержащееся в ст. 154 Модельного Земельного кодекса для государств - участников СНГ, принятого постановлением Межпарламентской Ассамблеи государств участников Содружества Независимых Государств от 4 декабря 2004 г. № 248 , хотя и в нем сделан акцент исключительно на обороне. В комментируемой статье закреплено, что «землями для нужд обороны признаются земли, предоставленные для размещения и постоянной деятельности войсковых частей, учреждений, военно-учебных заведений, предприятий и организаций вооруженных сил государства, выполняющих задачи в области обороны и безопасности, установленные законодательством» ${ }^{2}$.

При характеристике правового режима земель обороны и безопасности следует учитывать ряд особенностей.

Во-первых, земли промышленности и иного специального назначения, занятые объектами обороны и безопасности, объектами оборонного производства, объектами, обеспечивающими статус и защиту Государственной границы Российской Федерации, другими объектами, отнесенными к ведению Российской Федерации в соответствии со статьей 71 Конституции Российской Федерации, являются федеральной собственностью.

Принадлежность земель обороны и безопасности к данной форме собственности обусловливает ограничение оборотоспособности земельных участков из состава земель данного вида (ст. 27 ЗК РФ) $)^{3}$.

В соответствии с ЗК РФ из гражданского оборота изъяты земельные участки, занятые находящимися в федеральной собственности зданиями, строениями и сооружениями, в которых размещены для постоянной деятельности Вооруженные Силы Российской Федерации, другие войска, воинские формирования и органы; зданиями, строениями и сооружениями, в 
которых размещены военные суды; объектами организаций федеральной службы безопасности; объектами организаций федеральных органов государственной охраны; объектами использования атомной энергии, пунктами хранения ядерных материалов и радиоактивных веществ; объектами, в соответствии с видами деятельности которых созданы закрытые административно-территориальные образования; объектами учреждений и органов Федеральной службы исполнения наказаний; инженернотехническими сооружениями, линиями связи и коммуникациями, возведенными в интересах защиты и охраны Государственной границы Российской Федерации.

Изъятие из гражданского оборота означает, что земельные участки из состава земель обороны и безопасности не могут предоставляться в частную собственность, а также быть объектами сделок, предусмотренных гражданским законодательством.

Федеральный закон от 16.07.1998 г. № 102-Ф3 (ред. от 18.12.2006 г.) «Об ипотеке (залоге недвижимости)» закрепляет в числе прочего запрет на ипотеку имущества, изъятого из оборота, а также земельных участков, находящихся в государственной или муниципальной собственности (п.2 ст.6, п.1 ст. 63). Запрет залога земельных участков, на которых расположены организации государственного резерва, установлен п. 3 ст.4 Федерального закона от 29.12.1994 № 79-Ф3 (ред. от 02.02.2006) «О государственном материальном резерве».

Правила о недопустимости ипотеки недвижимого имущества применяются также к залогу прав арендатора по договору об аренде такого имущества, а также к залогу права постоянного (бессрочного) пользования земельным участком.

Земельные участки, предоставленные для обеспечения обороны и безопасности, а также оборонной промышленности, могут находиться в государственной или муниципальной собственности ${ }^{4}$. При этом оборот данных земельных участков является ограниченным (участки не 
предоставляются в частную собственность (за исключением случаев, установленных федеральными законами), могут устанавливаться ограничения прав правообладателей на землю).

Порядок использования отдельных видов земель, находящихся в федеральной собственности, а также установления зон с особыми условиями использования земель данной категории, если иное не установлено ЗК РФ, определяется Правительством Российской Федерации.

Так, Правительство Российской Федерации определяет порядок передачи исполнительными органами государственной власти отдельных земельных участков из земель, предоставленных для нужд обороны и безопасности, в аренду или безвозмездное срочное пользование юридическим лицам и гражданам для сельскохозяйственного, лесохозяйственного и иного использования 5 . На праве аренды (договорного, срочного и возмездного владения и пользования земельным участком) предоставляются только обособленные земельные участки обороны и безопасности, прошедшие государственный кадастровый учет. Не могут передаваться в аренду земельные участки изъятые из оборота, за исключением случаев установленных федеральными законами. При использовании земельных участков, предоставленных воинским частям, для производства сельскохозяйственной продукции в отношении данных участков распространяется порядок использования, применимый к землям сельскохозяйственного назначения. Согласно ст.3 Федерального закона от 24.07.2002 г. № 101-Ф3 «Об обороте земель сельскохозяйственного назначения» иностранные граждане, иностранные юридические лица, лица без гражданства, а также юридические лица, в уставном (складочном) капитале которых доля иностранных граждан, иностранных юридических лиц, лиц без гражданства составляет более чем 50 процентов, могут обладать земельными участками или долями в праве общей собственности на земельные участки из земель сельскохозяйственного назначения только на праве аренды. Таким образом, иностранным юридическим лицам, лицам без 
гражданства, а также юридическим лицам, в уставном (складочном) капитале которых доля иностранных граждан, иностранных юридических лиц, лиц без гражданства составляет более чем 50 процентов земельные участки обороны и безопасности для сельскохозяйственного использования могут предоставляться только на праве аренды.

По договору безвозмездного срочного пользования одна сторона (собственник земельного участка) передает земельный участок в безвозмездное временное пользование другой стороне (землепользователю), а последняя обязуется вернуть его в том состоянии, в каком она его получила, или в состоянии, обусловленном договором. В безвозмездное пользование, как и в аренду, передаются только обособленные земельные участки. Если землепользователь продолжает использовать земельный участок после истечения срока договора при отсутствии возражений со стороны собственника, договор считается возобновленным на тех же условиях на неопределенный срок.

При предоставлении земельных участков обороны и безопасности в аренду или безвозмездное срочное пользование для сельскохозяйственного, лесохозяйственного и иного использования земельные участки обороны и безопасности приобретают двойственную правовую природу. С одной стороны, эти участки сохраняют присущий им правовой режим в составе земель обороны и безопасности, с другой стороны - приобретают элементы правового режима земель сельскохозяйственного назначения, лесного фонда и иного использования, предусмотренного договором о предоставлении земельного участка.

Постановление Правительства РФ утверждении правил передачи отдельных земельных участков из земель, предоставленных для нужд обороны и безопасности, в аренду или безвозмездное срочное пользование юридическим лицам и гражданам для сельскохозяйственного, лесохозяйственного и иного использования» 
определяет условия передачи земель, предоставленных для нужд обороны и безопасности, временно не используемых для указанных нужд

Федеральные органы исполнительной власти, в которых федеральным законом предусмотрена военная служба (Министерство обороны Российской Федерации, МВД Российской Федерации, МЧС России, ФСБ России, ФСО России, СВР России, Служба специальных объектов при Президенте Российской Федерации, Главное управление специальных программ Президента Российской Федерации) формируют из земель обороны и безопасности, временно не используемых ими, перечни земельных участков, которые могут быть сданы в аренду или безвозмездное пользование 7 Указанные перечни включают в себя сведения о местоположении (адресе) и площади земельных участков, предполагаемых правах на них и разрешенном использовании земельных участков, а также о возможных ограничениях использования земельных участков. К перечням прилагаются проекты границ земельных участков.

Перечни земельных участков направляются в Федеральное агенство по управлению федеральным имуществом для рассмотрения возможности предоставления этих участков в аренду или безвозмездного срочного пользования. Юридическое лицо или гражданин, заинтересованные в получении земельного участка, направляют в Федеральное агентство по управлению федеральным имуществом заявление, в котором указывают цель использования земельного участка, его предполагаемые размеры, местоположение, а также испрашиваемое право на землю.

Федеральное агенство по управлению федеральным имуществом (его территориальный орган) принимает решение о предоставлении участка заявителю или об отказе в его предоставлении.

Правилами ограничена возможность автоматической пролонгации срока действия договоров с земельными участками обороны и безопасности. Не позднее чем за 3 месяца до окончания срока действия договора аренды земельного участка или договора безвозмездного срочного пользования 
земельным участком Федеральное агенство по управлению федеральным имуществом (его территориальный орган) уведомляет об этом заинтересованный федеральный орган исполнительной власти. Если в Федеральное агенство (его территориальный орган) не поступило заявление федерального органа исполнительной власти о необходимости использования земельного участка для нужд обороны и безопасности, Агенство принимает решение о продлении действующего договора.

Особый режим использования земель устанавливается Правительством Российской Федерации в закрытом административно-территориальном образовании (далее - ЗАТО). До настоящего времени соответствующий нормативный правовой акт Правительства РФ не принят. В Постановлениях Правительства РФ от 26.06.1998 г. № 655 «Об утверждении положения об обеспечении особого режима в закрытом административно-территориальном образовании, на территории которого расположены объекты Министерства Обороны Российской Федерации» (с изм. от 07.08.2005 г.), от 11.06.1996 г. № 693 (ред. от 08.08.2003 г.) «Об утверждении положения о порядке обеспечения особого режима в закрытом административно-территориальном образовании, на территории которого расположены объекты Министерства Российской Федерации по атомной энергии» понятие и содержание особого режима использования земель в закрытом административнотерриториальном образовании не раскрываются.

В соответствии со ст. 6 Закона РФ от 14 июля 1992 г. № 3297-1 «О закрытом административно-территориальном образовании» земли ЗАТО могут включать в себя земли населенных пунктов (городов, поселков и сельских населенных пунктов), земли промышленности, обороны и иные земли, предусмотренные земельным законодательством Российской Федерации ${ }^{8}$.

Земельные участки, занимаемые предприятиями и (или) объектами, по роду деятельности которых созданы ЗАТО, находятся в федеральной собственности и передаются в постоянное (бессрочное) пользование этим 
предприятиям и (или) объектам. Решения об отнесении иных земель, включая зоны безопасности и санитарно-защитные зоны, к землям федеральной собственности на территории конкретного ЗАТО принимаются Правительством РФ по согласованию с органами государственной власти субъектов РФ и органами местного самоуправления ЗАТО. Управление этими землями осуществляется Правительством РФ. Земельные участки ЗАТО, за исключением земель, находящихся в федеральной собственности, находятся в ведении органов местного самоуправления данного ЗАТО.

В ряде случаев порядок использования земельных участков для нужд обороны и безопасности напрямую регулируется нормами ЗК РФ. Например, в условиях чрезвычайного или военного положения использование земельных участков для нужд обороны и безопасности может осуществляться в порядке, установленном ст. 51 ЗК РФ: земельный участок может быть временно изъят у его собственника уполномоченными исполнительными органами государственной власти в целях защиты жизненно важных интересов граждан, общества и государства от возникающих угроз с возмещением собственнику земельного участка причиненных убытков (реквизиция) и выдачей ему документа о реквизиции.

Следующей особенностью правового режима земель обороны и безопасности является основание возникновения прав участников земельных правоотношений, связанных с данным видом земель, на что указывает и легальное определение «земель обороны и безопасности», содержащееся в ст. 87 ЗК РФ.

Законодательно установлены различные основания возникновения прав на земельные участки государственной собственности у Российской Федерации, ее субъектов и у муниципальных образований. Отнесение к виду той или иной государственной земельной собственности осуществляется при наличии хотя бы одного основания. Для земель обороны и безопасности таким правовым основанием является Федеральный закон от 31 мая 1996 г. № 61-Ф3 (в ред. от 04.12.2006 г.) «Об обороне». Согласно ч. 10 и 11 ст.1 
Федерального закона «Об обороне» земли, леса, воды и другие природные ресурсы, предоставленные Вооруженным Силам Российской Федерации, другим войскам, воинским формированиям и органам, находятся в федеральной собственности 9 . Земли, леса, воды и другие природные ресурсы, находящиеся в собственности субъектов Российской Федерации, органов местного самоуправления, в частной собственности, могут быть изъяты для нужд Вооруженных Сил Российской Федерации, других войск, воинских формирований и органов только в соответствии с законодательством Российской Федерации. Статья 49 ЗК РФ определяет обстоятельства, при которых возможно изъятие (в том числе путем выкупа) земельных участков для государственных или муниципальных нужд. К числу таких исключительных обстоятельств относится: выполнение международных обязательств Российской Федерации, а также размещение объектов использования атомной энергии, объектов обороны и безопасности при отсутствии других вариантов возможного размещения этих объектов ${ }^{10}$.

В-третьих, виды прав на земельные участки из состава земель обороны и безопасности зависят от целей использования данных земельных участков. Так, в целях обеспечения защиты и охраны Государственной границы Российской Федерации земельные полосы или участки для обустройства и содержания инженерно-технических сооружений и заграждений, пограничных знаков, пограничных просек, коммуникаций, пунктов пропуска через Государственную границу Российской Федерации и других объектов отводятся в постоянное (бессрочное) пользование. Право постоянного (бессрочного) пользования земельным участком означает обеспеченную законом возможность бессрочного, безвозмездного пользования чужим земельным участком, находящимся в государственной или муниципальной собственности, в пределах, установленных законом, иными правовыми актами и актом о предоставлении земельного участка в пользование. Нормы отвода земельных полос, размеры земельных участков, необходимых для обеспечения защиты и охраны Государственной границы Российской 
Федерации, порядок их использования, включая особенности хозяйственной, промысловой и иной деятельности, определяются законодательством Российской Федерации.

Законом РФ от 1 апреля 1993 г. № 4730-1 (в ред. от 30.12.2006 г.) «О государственной границе Российской Федерации» устанавливается, что пограничным органам отводится в бессрочное (постоянное) пользование земельная полоса шириной до 5 км, проходящая непосредственно вдоль Государственной границы на суше, а при необходимости - по берегу российской части вод пограничной реки, озера или иного водоема, в соответствии с установленными Правительством РФ нормами. Пограничные органы в пределах приграничной территории имеют право находиться на любых участках местности и передвигаться по ним при исполнении служебных обязанностей; требовать от владельцев, пользователей земельных участков в пограничной зоне выделения мест для передвижения пограничных нарядов, оборудования и содержания в надлежащем состоянии проходов через ограждения, переходов через другие препятствия ${ }^{11}$. По смыслу положений Закона в данном случае речь не идет об установлении сервитутов, поскольку возможность ограниченного пользования земельным участком допускается только в отношении собственников земли.

В целях недопущения переноса заразных болезней через Государственную границу может быть запрещено или ограничено содержание и выпас скота в полосе местности (карантинной полосе) вдоль Государственной границы на суше. Карантинная полоса, ее ширина, порядок ее ограждения, ветеринарный режим на ней устанавливаются Министерством сельского хозяйства Российской Федерации или по его поручению органами ветеринарного надзора субъектов Российской Федерации.

Для размещения объектов по разработке, изготовлению, хранению и утилизации оружия массового поражения, переработке радиоактивных и других материалов, военных и иных объектов в закрытых административно- 
территориальных образованиях земельные участки предоставляются в постоянное (бессрочное) пользование или в аренду.

Действующее законодательство предусматривает специальные требования к размещению и эксплуатации объектов по хранению и уничтожению химического оружия. Они установлены Федеральным законом от 02.05 .1997 г. № 76-Ф3 «Об уничтожении химического оружия» и конкретизированы в Положении о зоне защитных мероприятий, устанавливаемой вокруг объектов по хранению химического оружия и объектов по уничтожению химического оружия, утвержденном Постановлением Правительства Российской Федерации от 24.02.1999 г. № 208.

Вокруг объектов по хранению химического оружия и объектов по уничтожению химического оружия устанавливаются зоны защитных мероприятий, в пределах которых осуществляется специальный комплекс защитных мероприятий, направленных на обеспечение коллективной и индивидуальной защиты граждан, защиты окружающей среды от возможного воздействия токсичных химикатов вследствие возникновения чрезвычайных ситуаций. Специальный комплекс защитных мероприятий определяется планами действий по предупреждению возникновения чрезвычайных ситуаций при проведении работ по хранению, перевозке и уничтожению химического оружия и ликвидации их последствий, разрабатываемыми для каждого объекта отдельно.

Расчет площади зоны защитных мероприятий, устанавливаемой вокруг объектов, осуществляется, как правило, на этапе проектирования этих объектов согласно методике определения площади зоны защитных мероприятий, утвержденной Министерством обороны Российской Федерации по согласованию с заинтересованными федеральными органами исполнительной власти. На основании рассчитанных значений площади зоны защитных мероприятий осуществляется определение ее границ на местности. 
В случае если расчетное значение площади зоны защитных мероприятий окажется менее размера санитарно-защитной зоны, принятой для конкретного объекта, зона защитных мероприятий устанавливается по границе санитарно-защитной зоны. При прохождении границы зоны защитных мероприятий через административные границы населенного пункта (село, район, город и т.д.) этот пункт полностью включается в зону защитных мероприятий.

Принципиальное значение для обороноспособности и безопасности государства имеет вопрос о правосубъектности иностранных граждан и организаций в отношении земельных участков из состава земель обороны и безопасности.

Действующее законодательство позволяет иностранным субъектам покупать земельные участки в собственность или арендовать их, если иное не установлено федеральными законами ${ }^{12}$. Статья 15 ЗК РФ определяет, что иностранные граждане, лица без гражданства и иностранные юридические лица не могут обладать на праве собственности земельными участками, находящимися на приграничных территориях, перечень которых устанавливается Президентом РФ, и на иных, установленных особо территориях РФ в соответствии с федеральными законами ${ }^{13}$.

Некоторые особенности приобретения земельных участков иностранными гражданами, лицами без гражданства и иностранными юридическими лицами определены статьями 35 и 36 ЗК РФ. В соответствии с данными статьями иностранные субъекты - собственники зданий, строений, сооружений, находящихся на чужом земельном участке, в том числе находящихся в государственной или муниципальной собственности, имеют преимущественное право выкупа или аренды земельного участка. Президент РФ может установить перечень видов зданий, строений, сооружений, на которые это правило не распространяется ${ }^{14}$.

Других ограничений прав иностранных субъектов на земельные участки обороны и безопасности не предусмотрено. 
Необходимо отличать земли обороны и безопасности от земель (территорий), временно используемых для проведения учений и других мероприятий, связанных с нуждами обороны. Временно используемые для нужд обороны земельные участки у собственников земельных участков, землепользователей, землевладельцев и арендаторов земельных участков не изымаются. Использование этих земель осуществляется применительно к порядку, установленному для проведения изыскательских работ, а также для зон с особыми условиями использования.

Как уже отмечалось, земли, предоставленные воинским частям, могут также использоваться для производства сельскохозяйственной продукции и обеспечения питанием личного состава (подсобные хозяйства воинских частей). В этом случае на них распространяется режим использования земель сельскохозяйственного назначения.

Важным элементом правосубъектности участников правоотношений, возникающих по поводу земельных участков обороны и безопасности, является ответственность землепользователей и арендаторов за нарушение норм земельного законодательства. Должностные лица и граждане, совершившие земельные правонарушения, несут административную, дисциплинарную, материальную, гражданско-правовую и уголовную ответственность, а организации могут быть привлечены к административной и гражданско-правовой ответственности.

Статьи 7.1, 7.2, 7.10, 8.6 и 8.8 Кодекса об административных правонарушениях РФ устанавливают административную ответственность за самовольное занятие земельных участков, уничтожение специальных знаков на участках, самовольную переуступку права пользования землей, порчу земель и использование земель не по целевому назначению. В ст. 75 ЗК РФ предусмотрено, что должностные лица и работники организаций, виновные в совершении земельных правонарушений, несут дисциплинарную ответственность в случаях, если в результате ненадлежащего выполнения ими своих должностных или трудовых обязанностей организация понесла 
административную ответственность за проектирование, размещение и ввод в эксплуатацию объектов, оказывающих негативное воздействие на состояние земель, их загрязнение химическими и радиоактивными веществами, производственными отходами, сточными водами. Материальная ответственность за нарушения земельного законодательства носит регрессный характер и направлена на возмещение предприятиям, учреждениям и организациям имущественных потерь, понесенных по вине неправомерных действий их работников.

Привлечение виновных лиц к ответственности не освобождает их от гражданско-правовой обязанности возместить в полном объеме вред, причиненный в результате земельного правонарушения.

Уголовная ответственность за нарушения земельного законодательства предусмотрена ст. 170 и 254 Уголовного кодекса РФ за регистрацию незаконных сделок с землей и порчу земли.

Следующей характерной чертой правового режима земель обороны и безопасности является их зонирование и особые условия согласования градостроительных регламентов.

Градостроительное $\quad$ и $\quad$ земельное законодательство $\quad$ (ст.35 Градостроительного кодекса, ч. 1 ст. 85 ЗК РФ) предусматривают территориальные зоны следующих видов: жилые зоны; общественноделовые зоны; производственные зоны; зоны инженерной и транспортной инфраструктур; рекреационные зоны; зоны сельскохозяйственного использования; зоны специального назначения; зоны военных объектов; иные зоны режимных территорий ${ }^{15}$.

Земли обороны и безопасности могут располагаться как за границами населенных пунктов, так и в черте поселений (земельные участки, занятые объектами обороны и безопасности). Согласно ч.6 ст. 10 Градостроительного кодекса РФ на картах, содержащихся в схемах территориального планирования РФ, отображаются границы земель обороны и безопасности, а также планируемые границы этих земель. Схемы территориального 
планирования РФ, включающие в себя схемы планируемого размещения объектов обороны и безопасности, утверждаются в порядке, установленном законодательством в области обороны и законодательством о государственной тайне. На соответствующих картах субъектов РФ отображаются только существующие границы земель обороны и безопасности. Если предложения, содержащиеся в проекте схемы территориального планирования субъекта РФ, предполагают изменение существующих или планируемых границ земель обороны и безопасности, указанный проект подлежит согласованию с уполномоченным федеральным органом исполнительной власти (ст. 16 Градостроительного кодекса). Проект схемы территориального планирования муниципального района подлежит согласованию в порядке, установленном Правительством РФ, в случае, если предложения, содержащиеся в указанном проекте, предполагают изменение существующих или планируемых границ земель обороны и безопасности (ст.21 Градостроительного кодекса).

На картах, содержащихся в генеральных планах поселений и городских округов, отображаются границы земель обороны и безопасности (ст.23 Градостроительного кодекса). Изменение существующих или планируемых границ земель обороны и безопасности в проекте генерального плана подлежит согласованию в порядке, установленном Правительством РФ (ст.25 Градостроительного кодекса).

На земельных участках, предоставленных для нужд обороны и безопасности, действуют специальные градостроительные регламенты. В соответствии со ст. 21 Градостроительного кодекса Российской Федерации Постановлением Правительства Российской Федерации от 10.03.2000 г. № 221 утверждены Правила выдачи разрешений на строительство объектов недвижимости федерального значения, а также объектов недвижимости на территориях объектов градостроительной деятельности особого регулирования федерального значения. Согласно ч.ч. 16 и 17 данных Правил в зоне объектов военной инфраструктуры особые условия застройки, 
оформления документации и получения разрешений (специальных разрешений) на строительство определяются Государственным комитетом РФ по строительству и жилищно-коммунальному комплексу и Министерством Обороны Российской Федерации. Специальные разрешения на строительство объектов недвижимости, составляющих государственную тайну, выдаются на основании лицензий федеральной службы безопасности на проведение работ с использованием сведений, составляющих государственную тайну.

Одним из видов зон с особыми условиями использования территорий и согласования градостроительных регламентов являются зоны охраняемых объектов. Постановлением Правительства РФ от 20.06.2006 г. № 384 «Об утверждении Правил определения границ зон охраняемых объектов и согласования градостроительных регламентов для таких зон» регламентируется порядок определения границ зон охраняемых объектов ${ }^{16}$.

Зоны охраняемых объектов устанавливаются с целью обеспечения безопасности объектов государственной охраны и защиты охраняемых объектов. Размер зоны охраняемых объектов и ее границы определяются с учетом размера земельного участка, на котором расположены охраняемые объекты, застройки земельного участка и вокруг него, рельефа местности, а также иных условий, обеспечивающих безопасность объектов государственной охраны и охраняемых объектов. Расстояние от границ земельного участка, на котором расположены охраняемые объекты, до границ указанной зоны не должно превышать 1 км.

Проведение территориального землеустройства и осуществление государственного кадастрового учета земельного участка с расположенными на нем охраняемыми объектами возлагается на Роснедвижимость и Федеральную службу охраны Российской Федерации.

В целях обеспечения безопасности хранения вооружения и военной техники, другого военного имущества, защиты населения и объектов производственного, социально-бытового и иного назначения, а также охраны 
окружающей среды при возникновении чрезвычайных ситуаций техногенного и природного характера на прилегающих к арсеналам, базам и складам Вооруженных Сил Российской Федерации, других войск, воинских формирований и органов земельных участках могут устанавливаться запретные зоны. Назначение и порядок установления запретных зон определяется Положением об установлении запретных зон и запретных районов при арсеналах, базах и складах Вооруженных Сил Российской Федерации, других войск, воинских формирований и органов, утвержденном Постановлением Правительства Российской Федерации от 17.02.2000 г. № 135.

Запретная зона включает территорию, непосредственно примыкающую к территории военного склада, арсенала, базы. Ширина запретной зоны от внешнего ограждения территории военного склада устанавливается: для военных складов ракет, боеприпасов, взрывчатых и химических веществ, легковоспламеняющихся и горючих жидкостей - до 400 м; для военных складов вооружения и военного имущества - до 100 м. Обязательным требованием при установлении запретной зоны является обустройство 50метровой противопожарной полосы, непосредственно примыкающей к внешнему ограждению территории военного склада, в пределах которой осуществляются вырубка деревьев и кустарника и вспашка по всей ширине.

Для военных складов ракет, боеприпасов, взрывчатых и химических веществ, легковоспламеняющихся и горючих жидкостей устанавливается также запретный район шириной не менее 3 км от внешнего ограждения территории военного склада.

Границы запретной зоны и запретного района утверждаются руководителями органов исполнительной власти субъектов Российской Федерации, на территории которых находятся военные склады, по представлению органов военного управления, в ведении которых они находятся. Границы запретной зоны обозначаются на местности хорошо видимыми указателями и надписями на русском языке и языке субъекта 
Российской Федерации, на территории которого находится военный склад. Границы запретного района на местности не обозначаются.

На территории запретной зоны запрещается проживание граждан, нахождение граждан без специального разрешения, строительство объектов производственного, социально-бытового и иного назначения, устройство туристических лагерей и зон отдыха, оборудование стоянок автотранспорта, разведение открытого огня (костров), стрельба из огнестрельного оружия и проведение иных работ, за исключением противопожарных и других мероприятий по обеспечению безопасности военного склада. На территории запретного района запрещается строительство объектов производственного, социально-бытового и иного назначения, проведение ландшафтнореабилитационных, рекреационных и иных работ, создающих угрозу безопасности военному складу и сохранности находящегося там имущества. В случае особой необходимости строительство объектов производственного, социально-бытового и иного назначения на территории запретного района может разрешаться в каждом конкретном случае органами исполнительной власти субъектов Российской Федерации, на территории которых находятся военные склады, по согласованию с органами военного управления, в ведении которых они находятся.

На территории запретного района не допускается устройство стрельбищ и тиров, стрельба из огнестрельного оружия, а также проживание иностранных граждан. В воздушном пространстве над территорией запретного района не допускаются прокладка воздушных трасс и полеты самолетов, вертолетов и других летательных аппаратов. В зависимости от местных условий в запретной зоне и запретном районе органами местного самоуправления в пределах их полномочий и по представлению начальника военного склада могут устанавливаться и иные ограничения, в том числе на транзитный проезд, причал судов, рыболовство, охоту, купание и другие.

Характерным элементом правового режима земель обороны и безопасности являются особенности перевода земель обороны и 
безопасности из состава категории земель промышленности и иного специального назначения в другие категории. Эти особенности устанавливает ст.9 Федерального закона от 21.12.2004 г. № 172-ФЗ (в ред. от 18.12.2006 г.) «О переводе земель или земельных участков из одной категории в другую». Перевод земель обороны и безопасности, которые нарушены, загрязнены или застроены зданиями, строениями, сооружениями, подлежащими сносу (в том числе подземными), допускается при наличии утвержденного проекта рекультивации земель. Перевод земель, на которых осуществлялась связанная с нарушением почвенного слоя деятельность, в другую категорию допускается только после восстановления нарушенных земель в соответствии с утвержденным проектом рекультивации земель, за исключением случаев, если такой перевод осуществляется по ходатайству исполнительных органов государственной власти или органов местного самоуправления.

Необходимо также отметить особый характер лесопользования на землях обороны и безопасности. Порядок использования лесов, расположенных на землях обороны и безопасности, определяется Лесным кодексом РФ от 04.12.2006 г. Действующим лесным законодательством (ст. ст. 8 и 10 Лесного кодекса РФ) установлено наличие в стране двух категорий лесов: лесного фонда и лесов, не входящих в лесной фонд. Леса, не входящие в лесной фонд, расположены в городских поселениях, а также на землях обороны и безопасности. На этих землях, в том числе и в расположенных на них лесах, дислоцированы объекты федеральных органов исполнительной власти, в которых федеральным законом предусмотрена военная служба. В соответствии с ч. 4 ст.11 Лесного кодекса РФ в лесах, которые расположены на землях обороны и безопасности, может быть запрещено или ограничено пребывание граждан. Использование, охрана, защита и воспроизводство лесов, расположенных на землях обороны и безопасности, осуществляется на основе лесохозяйственных регламентов, утвержденных уполномоченным федеральным органом исполнительной власти. Федеральный орган 
исполнительной власти утверждает результаты государственной экспертизы проектов освоения лесов, расположенных на землях обороны и безопасности.

Последней особенностью правового режима земель обороны и безопасности выступает безвозмездность землепользования. Согласно ст. 389 Налогового кодекса РФ земельные участки, предоставленные для обеспечения обороны, безопасности и таможенных нужд, не являются объектами налогообложения.

Принцип безвозмездности использования земли и природных ресурсов закреплен в ряде федеральных законов, регулирующих статус соответствующих федеральных органов исполнительной власти, осуществляющих свою деятельность в сфере обороны и безопасности.

Так, ч. 11 ст. 7.1. Федерального закона от 03.04.1995 г. № 40-Ф3 (в ред. от 27.07.2006 г.) «О федеральной службе безопасности» определяет, что органы федеральной службы безопасности освобождаются от всех форм платы за использование природных ресурсов.

В соответствии со ст.5 Федерального закона от 06.02.1997 г. № 27-Ф3 (в ред. от 27.07.2006 г.) «О внутренних войсках Министерства внутренних дел РФ» земли для размещения и постоянной деятельности органов управления внутренними войсками, соединений, воинских частей (подразделений), военных образовательных учреждений высшего профессионального образования и учреждений внутренних войск безвозмездно предоставляются им в постоянное или временное пользование соответствующими органами государственной власти и органами местного самоуправления в пределах их полномочий.

Ст. 29 Федерального закона от 27.05.1996 г. № 57-Ф3 (в ред. от 29.12.2004 г.) «О государственной охране» закрепляет, что земельные участки, акватории, здания, строения, сооружения, оборудование и другое имущество, находящиеся в оперативном управлении федеральных органов государственной охраны, а также имущество, созданное (создаваемое) или приобретенное (приобретаемое) за счет средств федерального бюджета и 
иных средств, являются федеральной собственностью. Федеральные органы государственной охраны освобождаются от всех форм платы за пользование водными объектами. Любопытно, что в прежней редакции Федерального закона «О государственной охране» (от 30.06.2003 г. № 86-Ф3) федеральные органы государственной охраны освобождались от всех форм платы за землю и за пользование водными объектами. Не вполне понятно, по каким основаниям законодатель исключил формулировку, связанную с освобождением органов государственной охраны от платы за землю ${ }^{17}$.

Элементом правового режима земель обороны и безопасности выступает правовая охрана и мониторинг земель обороны и безопасности. Охрана земель обороны и безопасности осуществляется с учетом необходимости рационального использования данных земель, защиты их от вредных воздействий, а также восстановления земель и лесного фонда, подвергшихся деградации, загрязнению, захламлению, другим негативным воздействиям. В ст.14 ЗК РФ определен порядок использования земель, подвергшихся радиоактивному и химическому загрязнению. Содержание, особенности разработки, финансирования и реализации программ реабилитации радиационно-загрязненных земель обороны и безопасности регулирует Федеральный закон от 10 июля 2001 г. № 92-Ф3 «О специальных экологических программах реабилитации радиационно-загрязненных участков территории».

Мониторинг земель обороны и безопасности является составной частью мониторинга земель промышленности и иного специального назначения. Содержание мониторинга земель обороны и безопасности включает систематическое наблюдение за состоянием данного вида земель, выявление изменений земельных участков и их оценку. Мониторинг земель осуществляется уполномоченным федеральным органом исполнительной власти совместно с заинтересованными министерствами и ведомствами.

Таким образом, проведенный анализ правового режима земель обороны и безопасности позволяет выделить ряд особенностей их правового 
положения (принадлежность к государственной собственности, ограничения оборотоспособности, возникновение прав участников земельных правоотношений в силу Федерального закона «Об обороне», учет особенностей правового режима земель обороны и безопасности при проведении зонирования территорий, территориальном планировании и градостроительной деятельности, установление запретных зон, особенности перевода земель обороны и безопасности из состава категории земель промышленности и иного специального назначения в другие категории, особый характер лесопользования и безвозмездность землепользования), а также обозначить некоторые направления совершенствования правового регулирования земельных отношений, возникающих по поводу земель обороны и безопасности.

Несмотря на активную правотворческую деятельность в области использования земельного фонда и прав на земельные участки, нормативная база, регулирующая отношения по поводу земель обороны и безопасности, все еще не является целостной. Так, до настоящего времени не принят указ Президента Российской Федерации, касающийся установления перечней земельных участков, находящихся на приграничных территориях, которыми не могут обладать на праве собственности иностранные граждане, лица без гражданства, иностранные юридические лица (п.3 ст.15 ЗК РФ). Помимо указанного перечня в нормативном акте, регулирующем особенности землепользования на приграничных территориях, должны быть четко определены условия предоставления земельных участков в составе приграничных территорий в аренду иностранным гражданам, лицам без гражданства, иностранным юридическим лицам и российским юридическим лицам с иностранным участием. В данном нормативном правовом акте представляется целесообразным закрепить разрешенные цели использования, сроки аренды, ограничения по распоряжению, количеству и размерам земельных участков, арендуемых иностранными субъектами. 
Не разработан предусмотренный п.5 ст.35 ЗК РФ указ Президента Российской Федерации об утверждении перечня видов зданий, строений, сооружений, собственность на которые не дает права иностранным гражданам, лицам без гражданства и иностранным юридическим лицам преимущественного права покупки или аренды земельного участка. В данном перечне предлагается закрепить следующие виды зданий, строений, сооружений:

а) здания, строения, сооружения любого назначения, расположенные на приграничных территориях, перечень которых устанавливается Президентом Российской Федерации; территориях, прилегающих к внешним охраняемым (контролируемым) зонам закрытых (обособленных) военных городков, а также прилегающих к поселкам учреждений с особыми условиями функционирования;

б) здания, строения, сооружения любого назначения, расположенные менее чем в 1 км от мест размещения пунктов управления государством и Вооруженными силами Российской Федерации, иных специальных объектов мобилизационного назначения; мест дислокации Вооруженных сил Российской Федерации, других войск, воинских формирований и режимных (особо важных) объектов органов, в которых федеральным законом предусмотрена военная служба;

в) здания, строения, сооружения любого назначения, расположенные на земельных участках в пределах закрытых административно-территориальных образований, а также в пределах территорий с регламентированным посещением для иностранных граждан;

г) здания, строения, сооружения любого назначения, расположенные на на территориях, прилегающих к участкам для размещения наземных объектов космической инфраструктуры, являющихся федеральной собственностью; строения и сооружения (кроме торговых, бытового обслуживания, культурно-просветительных и подземных) на территориях, прилегающих к специальным охранным зонам воздушного транспорта, 
удаленным не менее чем на 10 км от границ аэродромов; здания нежилого назначения, строения и сооружения на территориях, прилегающих к узлам связи, радионавигационным объектам, объектам обслуживания военноморского флота;

д) здания нежилого назначения, строения (кроме торговых и бытового обслуживания) и сооружения, расположенные на землях историкокультурного назначения и особо ценных землях, в местах традиционного проживания и хозяйственной деятельности коренных малочисленных народов Российской Федерации и этнических общностей;

е) здания, строения, сооружения любого назначения, высота которых превышает 50 м;

ж) здания нежилого назначения, строения и складские сооружения, на территориях, прилегающих к водоохранным зонам;

з) здания, строения, сооружения любого назначения, расположенные в территориальных зонах сельскохозяйственного использования и военных объектов земель поселений.

В настоящее время отсутствует Постановление Правительства Российской Федерации, которое определяло бы особый режим использования земель в закрытом административно-территориальном образовании.

В целях упорядочения предоставления отдельных земельных участков обороны и безопасности в аренду или безвозмездное срочное пользование юридическим лицам и гражданам с учетом интересов обороноспособности и безопасности государства статью 22 ЗК РФ предлагается дополнить пунктом 6.1 следующего содержания: «Иностранный гражданин, лицо без гражданства, иностранное юридическое лицо - арендатор земельного участка, находящегося в государственной (или) муниципальной собственности, не вправе сдавать его в субаренду (поднаем), передавать свои права и обязанности по договору аренды другому лицу (перенаем), предоставлять земельный участок в безвозмездное срочное пользование, а 
также продавать арендные права и вносить их в качестве вклада в уставный капитал хозяйственных товариществ и обществ или паевого взноса в производственный кооператив».

В качестве альтернативного варианта возможно включение данных положений в Постановление Правительства РФ от 31.03.2006 г. № 176 «Об утверждении правил передачи отдельных земельных участков из земель, предоставленных для нужд обороны и безопасности, в аренду или безвозмездное срочное пользование юридическим лицам и гражданам для сельскохозяйственного, лесохозяйственного и иного использования». Установленные в настоящее время формы примерных договоров куплипродажи, безвозмездного срочного пользования и аренды земельных участков, утвержденные Распоряжением Минимущества от 02.09.2002 г. № 3070-р особых условий землепользования и ограничений по распоряжению земельными участками в интересах обороноспособности и безопасности государства не предусматривают.

Ограничения на распоряжение земельными участками обороны и безопасности арендаторами и землепользователями представляется целесообразным закрепить в формах примерных договоров аренды и безвозмездного срочного пользования земельными участками обороны и безопасности, которые должны быть разработаны Минэкономразвития и торговли Российской Федерации совместно с заинтересованными федеральными органами исполнительной власти, в которых федеральным законом предусмотрена военная служба.

Красинский Владислав Вячеславович, кандидат юридических наук

${ }^{1}$ См. Комментарий к Земельному кодексу Российской Федерации (постатейный) / Под ред. С.А. Боголюбова. М.: Былина, 2002. С.331-335; Земельное право / Под ред. С.А. Боголюбова. М.: Проспект, 2003. С. 335-338; Земельное право / Под ред. С.А. Боголюбова. М.: Норма - Инфра М, 2001. С. 282-283; Земельное право / Под ред. Б.В. Ерофеева. М.: 
МЦУПЛ, 1999. С. 451-453; Комментарий к Земельному кодексу Российской Федерации (вводный) / Под ред. Н.И. Калинина. М.: Юрайт-М, 2002. С.128-130; Земельное право / Под ред. О.И. Крассова. М.: Юрист, 2000. С.369-371; Крассов О.И. Земельное право современной России. М.: Дело, 2003. С. 382-396; Краснов Н.И. Теоретические основы правового режима земель специального назначения: автореф. дис...д-ра юрид. наук. М.,1966; Земельное право / Под ред. В.Х. Улюкаева. М.: Былина, 2002. С.331-332; Комментарий к Земельному кодексу Российской Федерации / Под ред. Г.В.Чубукова, М.Ю. Тихомирова. М.: 2002 С.396-401.

${ }^{2}$ См. Информационный бюллетень Межпарламентской Ассамблеи СНГ. 2005. № 35. Следует отметить, что Модельный Земельный кодекс для государств - участников СНГ оказал заметное влияние и на региональных законодателей в Российской Федерации. Так, согласно статье 92 Закона Челябинской области от 10.04.1998 г. № 39-30 «О земельных отношениях» (в настоящее время утратил силу) землями для нужд обороны признавались земли, предоставленные для размещения и постоянной деятельности войсковых частей, учреждений, военно-учебных заведений, предприятий и организаций Вооруженных Сил Российской Федерации и других войск, выполняющих задачи в области обороны и безопасности, установленные законодательством Российской Федерации.

${ }^{3}$ В зарубежных странах правовой режим земель военного назначения имеет сходные черты с правовым режимом земель обороны и безопасности в России. К примеру, в США наиболее важные земли, обеспечивающие осуществление полномочий федеральных органов и органов штатов, изъяты из гражданского оборота и находятся в исключительной собственности федерации или штата. Право собственности федерации на земли для военных целей и ограничения их оборота регулируются книгой 50 Свода законов США «Армейское имущество и военные объекты». В соответствии с законом Чешской Республики «О лесах» право собственности на сельскохозяйственные и лесные участки в военных округах не подлежит переходу. См. Земельный участок: собственность, аренда и иные права в Российской Федерации и иностранных государствах / Под ред. В.В. Залесского. М., 2005. С. 25.

4 Анализ положений ЗК РФ и законов субъектов Российской Федерации, регулирующих земельные отношения, не позволяет согласиться с мнением ряда специалистов в области земельного права о том, что земли обороны и безопасности следует относить только к федеральной собственности. См. Н.Б. Головина. Земли обороны и безопасности - федеральная собственность // Имущественные отношения в Российской Федерации. 2005 . № 4.

${ }^{5}$ В соответствии со ст. 24 ЗК РФ в безвозмездное срочное пользование земельные участки, находящиеся в государственной или муниципальной собственности, могут предоставляться государственным или муниципальным учреждениям, казенным предприятиям, а также органам государственной власти и органам местного самоуправления - не более чем на 1 год; религиозным организациям - на срок строительства ими зданий, строений или сооружений религиозного назначения; лицам, с которыми заключен государственный или муниципальный контракт на строительство объекта недвижимости за счет средств соответствующего бюджета - на срок строительства объекта.

${ }^{6}$ Действие Правил не распространяется на земельные участки, предназначенные для обеспечения деятельности особорежимных объектов Российской Федерации. В соответствии со ст. 5 Закона РФ от 21.07.1993 г. № 5485-1 «О государственной тайне» и пунктами 22-24 Указа Президента РФ от 30.11.1995 г. № 1203 (ред. от 11.02.2006 г.) «Об утверждении перечня сведений, составляющих государственную тайну», сведения о выборе, отводе земельных участков для строительства или эксплуатации объектов, не подпадающих под обязательства РФ по международным договорам, для строительства или эксплуатации специальных объектов, запасных пунктов управления федеральных 
органов исполнительной власти, ядерных оружейных объектов, составляют государственную тайну РФ.

7 Перечень войск, воинских формирований и органов, в которых установлена военная служба, определяется ст.1 Федерального закона от 31 мая 1996 г. № 61-Ф3 (в ред. от 04.12.2006 г.) «Об обороне» и ст. 2 Федерального закона от 28.03.1998 г. № 53-Ф3 (ред. от 06.01.2007 г.) «О воинской обязанности и военной службе».

8 Поскольку ЗК РФ предусмотрен такой вид земель в составе земель промышленности и иного специального назначения, как земли обороны и безопасности, представляется целесообразным в текст ч. 1 ст. 6 Закона РФ от 14 июля 1992 г. № 3297-1 «О закрытом административно-территориальном образовании» после слов «земель обороны» добавить словосочетание «и безопасности». Далее без изменений.

${ }_{9}^{9}$ В соответствии с ч.1 ст. 7.1 Федерального закона от 03.04.1995 г. № 40-ФЗ (в ред. от 27.07.2006 г.) «О федеральной службе безопасности» земельные участки и имущество органов федеральной службы безопасности (в том числе здания, сооружения, оборудование), созданное (создаваемое) или приобретенное (приобретаемое) за счет средств федерального бюджета и иных средств, являются федеральной собственностью. Аналогичные положения закреплены в ст. 29 Федерального закона от 27.05.1996 г. № 57Ф3 (в ред. от 29.12.2004 г.) «О государственной охране», ст. 5 Федерального закона от 06.02.1997 г. № 27-Ф3 (в ред. от 27.07.2006 г.) «О внутренних войсках Министерства внутренних дел Российской Федерации».

${ }^{10} \mathrm{~B}$ иностранных государствах земельные участки могут принудительно изыматься для публичных надобностей. Например, по законодательству Республики Польша земельные участки могут быть принудительно изъяты у собственников для строительства и эксплуатации оборонных объектов, объектов обеспечения общественной безопасности, включая тюрьмы и колонии для несовершеннолетних. Ст. 1 Закона Хорватии «Об отчуждении недвижимого имущества» допускает принудительное отчуждение земли на возмездных началах при строительстве сооружений для нужд органов правосудия, армии и полиции. В английском праве приобретение земли для военных целей (в частности, для размещения воинских частей) осуществляется на основании специальных законов (Military Land Act). См. Земельный участок: собственность, аренда и иные права в Российской Федерации и иностранных государствах / Под ред. В.В. Залесского. М., 2005. С. 96, 184, 187.

${ }^{11}$ См. Ст. 30 Закона РФ от 1 апреля 1993 г. № 4730-1 (в ред. от 30.12.2006 г.) «О государственной границе Российской Федерации».

12 Интерес представляет зарубежный опыт регулирования прав иностранных субъектов на землю. Так, Закон Республики Польша от 24.03.1920 г. «О приобретении иностранцами недвижимости» ограничивает возможность приобретения недвижимости иностранными гражданами без предварительного разрешения. Иностранец должен получить разрешение на покупку земли, выдаваемое министром внутренних дел с согласия министра национальной обороны. Если речь идет о сельскохозяйственных угодьях, то необходимо также согласие министра сельского хозяйства и продовольствия. Разрешение действительно в течение 1 года с момента выдачи. В Австрии для приобретения земли иностранными гражданами требуется согласие комиссии по земельным участкам. См. Земельный участок: собственность, аренда и иные права в Российской Федерации и иностранных государствах / Под ред. В.В. Залесского. М., 2005. C. $126,131$.

13 Указ Президента РФ об установлении перечней земельных участков, находящихся на приграничных территориях, которыми не могут обладать на праве собственности иностранные граждане, лица без гражданства, иностранные юридические лица, до настоящего времени не принят. 
14 Указ Президента РФ об утверждения перечня видов зданий, строений, сооружений, собственность на которые не дает права иностранным гражданам, лицам без гражданства и иностранным юридическим лицам преимущественного права покупки или аренды земельного участка, до настоящего времени не принят.

15 Более подробно о зонировании территорий см. Анисимов А. Зонирование территорий городских и сельских поселений: виды и правовое значение // Право и экономика. 2004. № 6.

${ }^{16}$ В связи с принятием Постановления Правительства РФ от 20.06.2006 г. № 384 «Об утверждении Правил определения границ зон охраняемых объектов и согласования градостроительных регламентов для таких зон» утратило силу Постановление Правительства Российской Федерации от 07.12. 2004 г. № 741 «О границах объектов градостроительной деятельности особого регулирования федерального значения, устанавливаемых вокруг объектов, относящихся к федеральной собственности и находящихся в ведении Управления делами Президента Российской Федерации и (или) Федеральной службы охраны Российской Федерации».

17 В письмах Министерства финансов Российской Федерации от 17.08.2006 г. № 0306-02-02/112, от 29.09.2006 г. № 03-06-02-02/124, Федеральной налоговой службы от 19.09.2006 г. № ММ-6-21/937@ «О налоге на имущество организаций и земельном налоге», от 09.11.2006 г. № MМ-6-21/109@ «О земельном налоге» изложена позиция о недопустимости взимания земельного налога в отношении земельных участков, ограниченных в обороте и предоставленных для обеспечения обороны, безопасности и таможенных нужд. 